\title{
DATA MODEL CUSTOMIZATION FOR YII BASED ERP APPLICATION
}

\author{
Andre Leander ${ }^{1}$, Adi Wibowo ${ }^{1 *}$, Lily Puspa Dewi ${ }^{1}$ \\ ${ }^{1}$ Program Studi Teknik Informatika, Fakultas Teknologi Industri, Universitas Kristen Petra \\ Jl. Siwalankerto 121-131, Surabaya 60236. Telp. (031) 2983455, Fax. (031) 8417658 \\ E-mail: leeshienwen@gmail.com, adiw@petra.ac.id, lily@petra.ac.id \\ *Korespondensi penulis
}

\begin{abstract}
Abstrak: Semakin berkembangnya bisnis perusahaan UD. Logam Utama, memicu kebutuhan akan informasi secara cepat dan akurat guna meningkatkan kinerja, efisiensi, kontrol dan value perusahaan. Perusahaan membutuhkan sebuah sistem dimana setiap fungsional perusahaan saling terintegrasi. ERP merupakan aplikasi yang memiliki sistem yang mampu memusatkan database dan mampu dikonfigurasi sesuai dengan proses bisnis perusahaan. Sebelum memulai pengembangan aplikasi, dilakukan analisa dan desain terhadap proses bisnis perusahaan. Tahap desain menghasilkan sejumlah pemodelan yang nantinya digunakan untuk membuat aplikasi. Hasil akhir dari pengembangan aplikasi ini adalah sebuah aplikasi ERP yang mampu dikonfigurasi dengan proses bisnis perusahaan. ERP yang dikembangkan mencakup modul pergudangan dan produksi, modul pembelian, modul penjualan, dan modul akuntansi.
\end{abstract}

Kata kunci: Enterprise Resource Planning (ERP), Yii Framework, Business Architecture, Technology Architecture, Software, Agricultural Company.

\begin{abstract}
As UD. Logam Utama's business grow, trigger the need of fast and accurate information in order to improve performance, efficiency, control and company's values. The company needs a system that can integrate each functional area. ERP has centralized database and able to be configured, according to company's business processes.First phase of application development is analysis and design the company's business processes. The design phase produce a number of models that will be used to created application.The final result of application development is an ERP application that can be configured with the company's business process. The ERP application consist of warehouse or production module, purchasing module, sales module, and accounting module.
\end{abstract}

Keywords: Enterprise Resource Planning (ERP), Yii Framework, Business Architecture, Technology Architecture, Software, Agricultural Company.

\section{PENDAHULUAN}

Perkembangan teknologi yang sangat pesat dewasa ini memberikan pengaruh yang besar dalam bidang perekonomian terutama terhadap sejumlah perusahaan dalam persaingannya di dunia bisnis. Penerapan sistem informasi merupakan salah satu langkah yang digunakan untuk membantu kinerja perusahaan agar menjadi lebih baik, lebih efisien, dan lebih terkontrol dalam hal mengurangi kesalahan ketika menjalankan bisnis. Hal ini sangat penting karena dengan penerapan sistem informasi, perusahaan dapat meningkatkan value kepada pembeli dan menjadi dukungan bagi perusahaan untuk bersaing dengan perusahaan lainnya.

UD Logam Utama merupakan sebuah perusahaan yang mengelola hasil bumi terutama hasil pertanian di Luwuk, Sulawesi Tengah. Dalam menjalankan proses bisnis operasionalnya, perusahaan masih melakukannya secara manual. Hal ini menyebabkan pekerjaan menjadi lambat dan kurangnya kontrol menyebabkan proses pencatatan dan perhitungan sangat rentan terjadi kesalahan. Sebagai contoh sering kali perusahaan mengalami kesulitan dalam mengurusi para penjual yang sangat banyak dan membuat penjual tersebut menunggu terlalu lama untuk proses pembayaran. Terdapat juga kejadian dimana perusahaan salah menghitung nota sehingga pihak penjual merasa dirugikan.

Selain itu tidak adanya konsistensi terhadap data terbaru dan lambatnya aliran informasi mengakibatkan keterlambatan pengambilan keputusan atau juga bisa membuat keputusan yang salah.

\section{TINJAUAN PUSTAKA}

\section{Enterprise Resource Planning}

Enterprise Resource Planning merupakan sistem perusahaan dimana antara satu sistem fungsional dengan sistem fungsional yang lain saling berkaitan dan bekerja sama. Hal ini dimungkinkan 
dengan menggunakan software yang mampu mengintegrasikan semua modul di masing-masing fungsional/divisi di dalam sebuah perusahaan [1]. Software membantu perusahaan untuk mengelola dan menampilkan informasi secara real time antar divisi yang berbeda dengan menggunakan database tertentu. Selain itu, software ERP haruslah mampu untuk dikonfigurasi sehingga dapat digunakan diberbagai komputer hardware dan network yang berbeda. Software ERP sangatlah mahal dan sangat kompleks oleh karena itu software ini memang dikhususkan untuk perusahaan [1].

Dalam penerapan ERP bisa saja tidak meningkatkan produktivitas dan keuntungan kompetitif apabila penerapan sistem tidak dijalankan dengan baik [2]. Penerapan ERP di dalam perusahaan memiliki siklus hidup yang disebut sebagai Siklus Hidup Pengembangan Sistem ERP Fase yaitu fase perencanaan, fase analisis, fase desain, fase implementasi, dan fase dukungan teknis [3]. Terdapat delapan faktor yang dapat mempengaruhi implementasi ERP yaitu: data-data yang diberikan (Data Provided), sistem parallel (Parallel Systems), pelatihan dan pengujian (Training and Testing), harapan dari sistem ERP (Expectation from the ERP System), kualitas pekerja (Employee Retention), desain dan pengujian (Design and Testing), kustomisasi ERP harus kurang dari $30 \%$, dan semua stakeholder harus diidentifikasi pada tahap awal pengembangan termasuk pelanggan dan vendor [4].

\section{Organizational Data, Master Data, and Transaction Data}

Organizational data digunakan untuk merepresentasikan struktur dari sebuah perusahaan. Contoh struktur dari perusahaan seperti perusahaan, divisi, pabrik, gudang, area penyimpanan, dan area penjualan.

Master data merupakan representasi entitas terkait dengan berbagai macam proses. Beberapa entitas yang termasuk master data di dalam sistem ERP antara lain data supplier/vendor, data customer, dan data material/produk. Data material/produk merupakan master data yang paling umum dan paling banyak digunakan di berbagai macam proses seperti proses pembelian, proses penjualan, dan proses produksi. Oleh karena itu data material menjadi data yang paling kompleks dan luas dibandingkan master data yang lain. Data material di dalam sistem ERP tersusun atas basic data, material group, material type, dan data terkait dengan proses tertentu (purchasing data, sales data, warehouse data, management accounting data, dan lain-lain) [5].
Transaction data mencerminkan hasil dari pengeksekusian proses atau transaksi. Contoh transaction data antara lain tanggal, jumlah, harga, dan pembayaran serta waktu pengiriman. Sehingga transaction data merupakan kombinasi dari organizational data, master data, dan situational data. Situational data adalah data yang sifatnya spesifik terhadap kondisi pengeksekusian proses, contoh siapa (who), apa (what), kapan (when), dan di mana (where) [5].

\section{$X M L$}

eXtensible Markup Language atau XML merupakan sebuah dokumen yang didesain dan dibuat untuk menyusun data, sebagai media pengirim, dan penyimpan data. Berbeda dengan HTML dimana memiliki tag yang sudah ditentukan, dalam XML anda bisa mendefinisikan tag anda sendiri. Contoh isi dari dokumen XML dapat dilihat pada Gambar 2.39.

\section{Yii Framework}

Yii ("Yes It Is!") merupakan sebuah framework open source yang disusun dengan menggunakan PHP5 untuk pengembangan aplikasi berbasis web. Yii sering digunakan untuk pengembangan sebuah aplikasi yang sifatnya rapid development dan juga sangat membantu untuk menghasilkan sebuah aplikasi yang extremely efficient, extensible, dan maintainable.

\section{$\underline{\text { Model-View-Controller }}$}

Yii mengimplementasi pola desain model, view, dan controller (MVC) dimana telah diadobsi secara luas oleh sejumlah pemrograman Web. MVC bertujuan untuk memisahkan logika bisnis (business logic) dari tampilan aplikasi (user interface), sehingga para pengembang aplikasi dapat lebih mudah untuk mengubah masing-masing bagian tanpa mempengaruhi yang lain. Dalam MVC, model menggambarkan informasi (data) dan aturan (business rules). View berisikan elem-elemn yang digunakan untuk membentuk tampilan aplikasi (user interface) seperti teks atau kolom inputan. Sedangkan controller berfungsi untuk memanajemen komunikasi antara model dan view. Pada Gambar 1 mengilustrasikan struktur statis dari sebuah aplikasi Yii.

\section{$\underline{\text { Gii }}$}

Yii dilengkapi dengan dengan sebuah Webbased code generator tool yang disebut Gii. Gii merupakan sebuah tool yang berfungsi untuk 
membuat model, controller, form, dan view melalui tampilan aplikasi, sehingga pengembang tidak perlu membuat MVC secara manual. Gii dapat di kembangkan secara bebas oleh pengguna Yii seperti mengubah isi dari script yang dihasilkan dengan menggunakan generator dasar Yii atau dengan membuat generator yang baru.

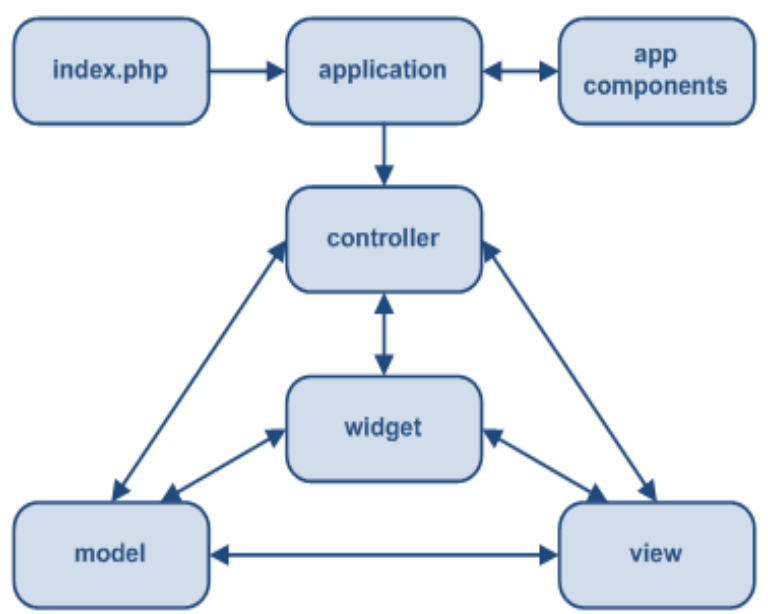

Gambar 1. Struktur Statis dari Aplikasi Yii

\section{ANALISA DAN DESAIN}

Fitur kustomisasi yang dimiliki oleh aplikasi ERP didesain untuk menggunakan file XML sebagai media penyimpanan data kustomisasi dan pola struktur data. Pada tahap ini perlu dilakukan analisa terhadap struktur data yaitu dengan mendaftarkan data-data apa saja yang dibutuhkan, rules untuk datadata tersebut, dan bagaimana data dapat digunakan ketika fitur kustomisasi dijalankan. Struktur data tersebut disimpan di dalam XML schema dan digunakan ketika membuat file XML yang menyimpan data kustomisasi. File XML yaitu instance dari XML Schema selanjutnya digunakan pada table generator, model generator, dan form generator.

\section{Desain XML Schema}

XML schema merupakan sebuah file XML yang digunakan sebagai panduan penulisan Instance XML. XML table extension adalah sebuah file Instance XML dimana aplikasi membaca isi dari XML tersebut dan membuatkan table baru di database sesuai dengan isi dari XML. Isi dari XML schema dapat dilihat pada Gambar 2.

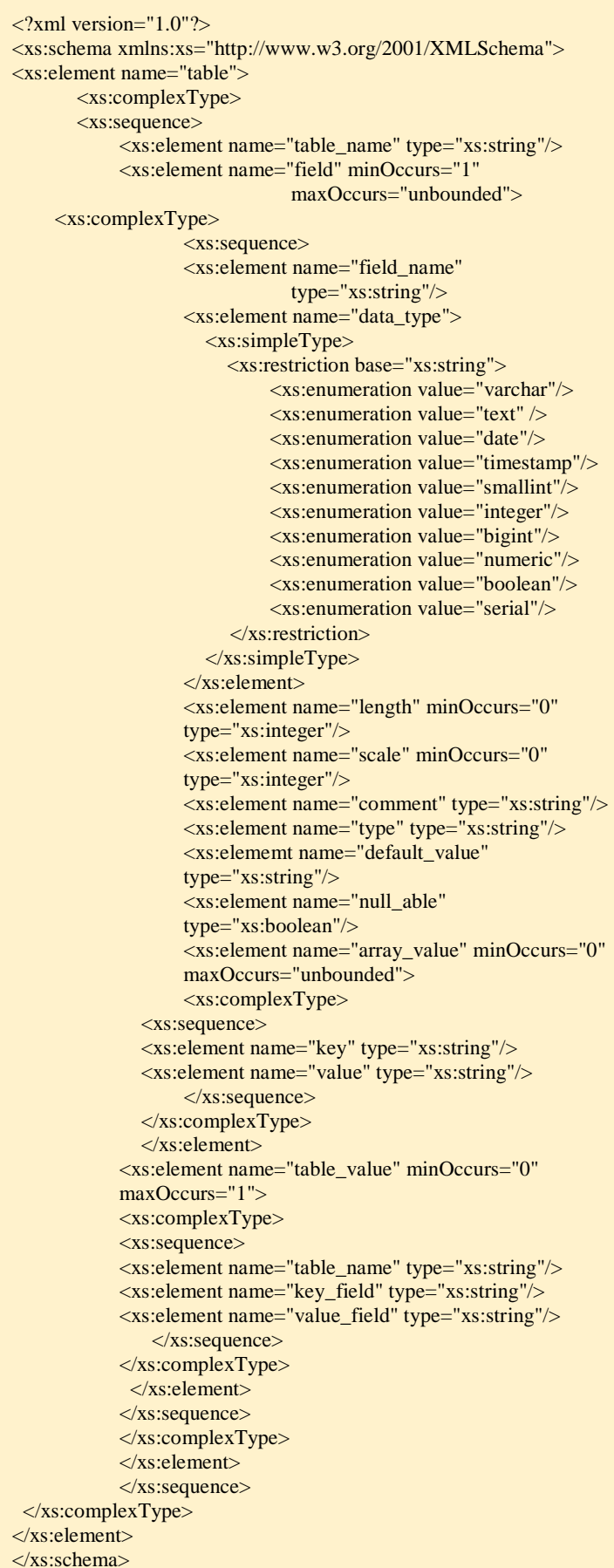

Gambar 2. XML Schema 
Penjelasan setiap elemen yang terdapat pada Gambar 2 dapat dilihat pada Tabel 1.

Tabel 1. Tabel Penjelasan Elemen-Elemen XML dari XMLSchema

\begin{tabular}{|c|c|c|}
\hline & Nama Elemen & Keterangan \\
\hline 1 & table_name & Menyimpan nama table exstension \\
\hline 2 & field & $\begin{array}{l}\text { Menyimpan daftar attribute atau } \\
\text { field yang dimiliki oleh table } \\
\text { extension }\end{array}$ \\
\hline 3 & field_name & $\begin{array}{l}\text { Menyimpan nama attribute atau } \\
\text { field }\end{array}$ \\
\hline 4 & data_type & $\begin{array}{l}\text { Menyimpan tipe data dari attribute } \\
\text { atau field }\end{array}$ \\
\hline 5 & length & $\begin{array}{l}\text { Menyimpan panjang dari attribute } \\
\text { atau field }\end{array}$ \\
\hline 6 & scale & $\begin{array}{l}\text { Menyimpan nilai belakang koma } \\
\text { dari attribute atau field yang } \\
\text { memiliki tipe data numeric, decimal, } \\
\text { money, atau serial }\end{array}$ \\
\hline 7 & comment & $\begin{array}{l}\text { Menyimpan komentar untuk } \\
\text { attribute atau field }\end{array}$ \\
\hline 8 & type & $\begin{array}{l}\text { Menyimpan jenis dari attribute atau } \\
\text { field seperti Primary Key, Foreign } \\
\text { Key, dan Normal Field }\end{array}$ \\
\hline 9 & default_value & $\begin{array}{l}\text { Menyimpan nilai awal dari attribute } \\
\text { atau field apabila tidak memiliki } \\
\text { nilai }\end{array}$ \\
\hline 10 & null_able & $\begin{array}{l}\text { Menyimpan pengaturan apakah } \\
\text { attribute atau field boleh dibiarkan } \\
\text { kosong atau tidak. }\end{array}$ \\
\hline 11 & array_value & $\begin{array}{l}\text { Menyimpan daftar pilihan nilai } \\
\text { attribute atau field }\end{array}$ \\
\hline 12 & key & Menyimpan nilai dari array_value \\
\hline 13 & value & $\begin{array}{l}\text { Menyimpan data yang ditampilkan } \\
\text { oleh key array_value }\end{array}$ \\
\hline 14 & table_value & $\begin{array}{l}\text { Menyimpan daftar pilihan nilai } \\
\text { dimana nilai berasal dari table lain. }\end{array}$ \\
\hline 15 & table_name & $\begin{array}{l}\text { Menyimoan nama table yang } \\
\text { menjadi table_value }\end{array}$ \\
\hline 16 & key_field & $\begin{array}{l}\text { Menyimpan attribute atau field } \\
\text { kunci dari table yang menjadi } \\
\text { table_value }\end{array}$ \\
\hline 17 & value_field & $\begin{array}{l}\text { Menyimpan attribute atau field dari } \\
\text { table_value yang menjadi referensi } \\
\text { nilai }\end{array}$ \\
\hline
\end{tabular}

\section{Desain Template Class Model, Template Form, dan Template View}

Template class model, template form, dan template view adalah file-file PHP yang berisikan script code yang digunakan sebagai pola dasar pembuatan file model, form, dan view extension. Pada Gambar 3, Gambar 4, dan Gambar 5 merupakan desain template class model, template form, dan template view.

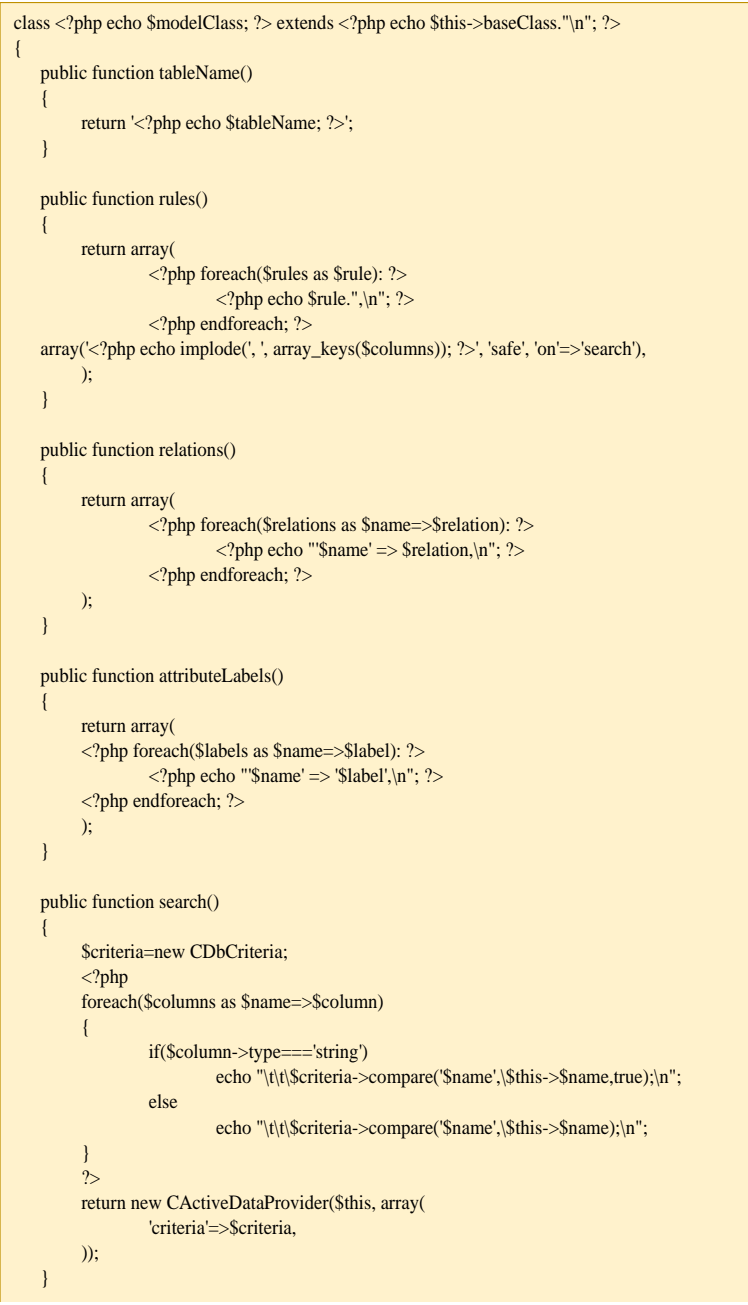

Gambar 3. Template Class Model

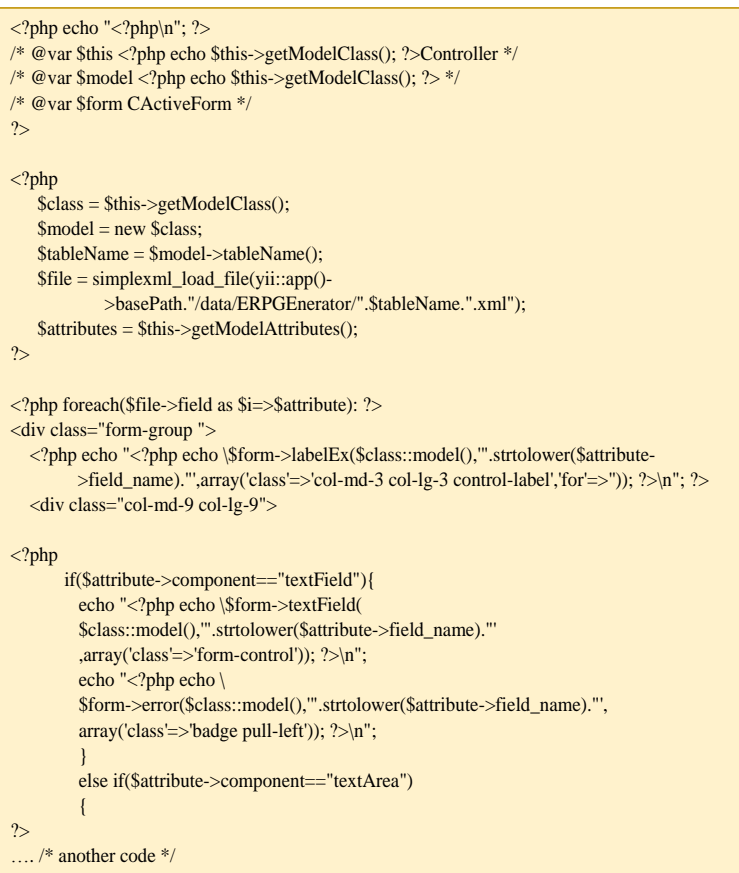

Gambar 4. Template File Form 


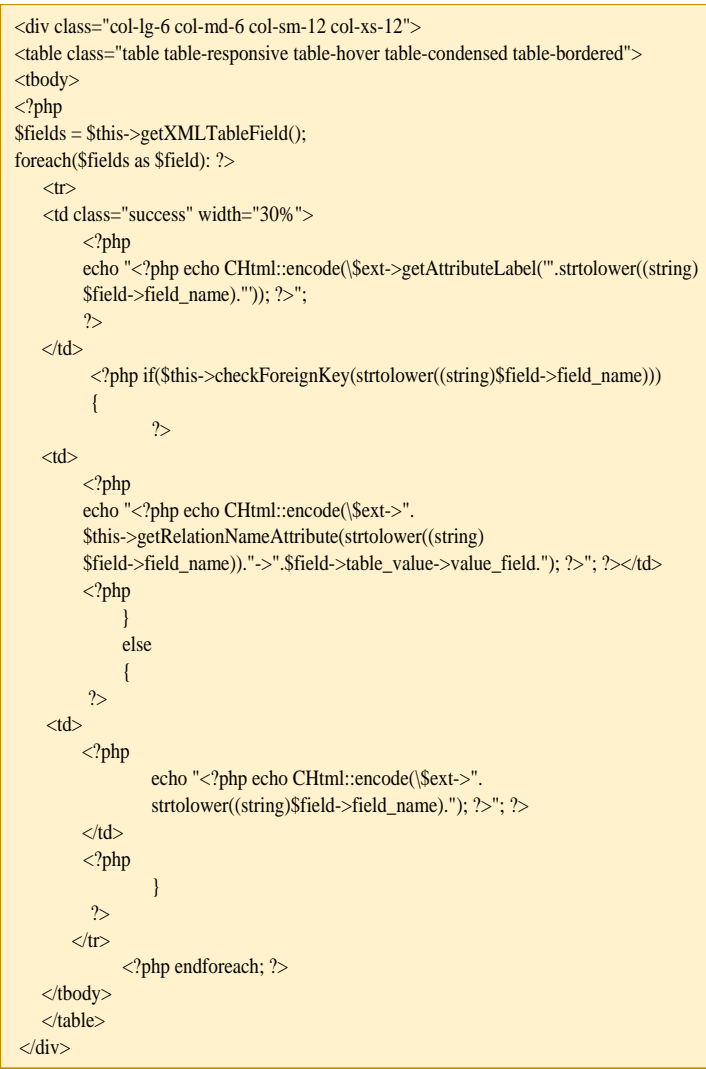

Gambar 5. Template File View

\section{Cara Kerja ERP Generator}

ERP generator terbagi atas tiga bagian yaitu table generator, model generator, dan form generator. Table generator berfungsi untuk membuat table baru di database yang merupakan ekstensi dari table dasar yang telah tersedia. Table baru tersebut kemudian dibuat class model dengan menggunakan model generator. Model yang dihasilkan dari model generator kemudian dipakai untuk membuat file form tampilan untuk mengisi data dan file view untuk menampilkan data dengan menggunakan form generator.

Table generator bekerja dengan pertama-tama membuat file XML table extension. Isi dari file XML disesuaikan dengan data yang diberikan oleh pengguna. Dari file XML table extension tersebut kemudian dibuat table baru di database dengan mengeksekusi perintah SQL secara otomatis oleh aplikasi. Sebelum membuat table baru, nama table tersebut diperiksa terlebih dahulu apakah telah dipakai atau tidak terpakai. Ilustrasi cara kerja table generator dapat dilihat pada Gambar 6.

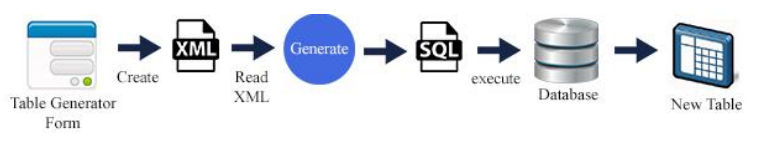

Gambar 6. Ilustrasi cara kerja table generator
Model generator bekerja dengan membaca file XML table extension dan table extension yang ada di dalam database. Model generator menggunakan template class model sebagai dasar untuk membuat model baru. Model generator membaca nama table parent, nama table ekstensi, daftar attributes dan nama label attributes, daftar relasi, dan rule attributes dari file XML table extension dan table extension di database, kemudian menggunakannya pada template class model. Setelah membaca data, model generator membuat file baru pada folder model di modul yang dipilih oleh pengguna. Ilustrasi cara kerja model generator dapat dilihat pada Gambar 7.

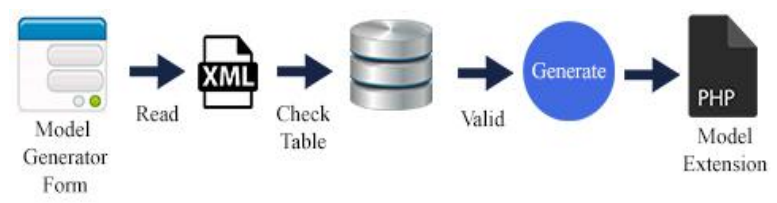

Gambar 7. Ilustrasi cara kerja model generator

Form generator bekerja dengan membaca model ektensi dan membuat dua file baru yaitu file form dan file view. Form generator menggunakan panduan pembuatan yaitu dengan template form. Form generator terlebih dahulu membaca isi dari class model dan membuat daftar komponen yang disesuaikan dengan daftar komponen yang tersimpan file XML table extension. Dengan menggunakan fungsi yang dimiliki form generator, aplikasi membuat 2 file baru dengan lokasi penyimpanan pada folder view dari modul yang dipilih pengguna. Isi dari 2 file baru tersebut disesuaikan dengan isi template form dan view. Ilustrasi cara kerja form generator dapat dilihat pada Gambar 8.

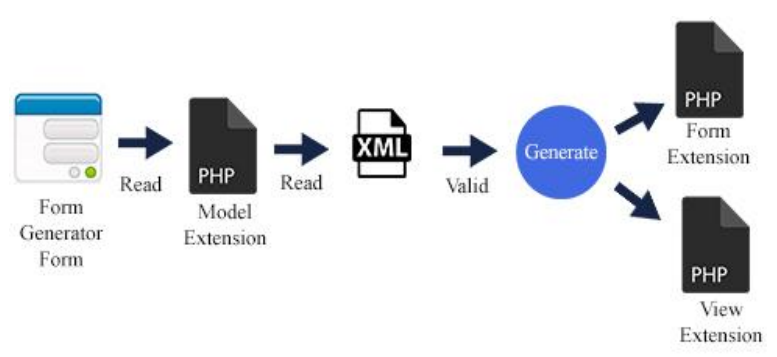

Gambar 8. Ilustrasi cara kerja form generator

\section{HASIL}

Hasil aplikasi berupa program ERP yang dapat dikonfigurasi. Konfigurasi meliputi penambahan table ekstensi dari table yang sudah ada sebelumnya. Selain itu konfigurasi meliputi pembuatan class model baru dan file view sebagai form dari model. Tampilan form yang digunakan untuk membuat table baru dapat dilihat pada Gambar 9. 
Selain itu juga terdapat form untuk membuat model baru sesuai dengan table yang dibuat sebelumnya. Tampilan form model generator dapat dilihat pada Gambar 10.

Hasil eksekusi dari model generator pada Gambar 10 menghasilkan file model extension baru dimana disimpan pada folder khusus (ext) pada modul yang dipilih pengguna. Isi dari file model extension dapat dilihat pada Gambar 11.

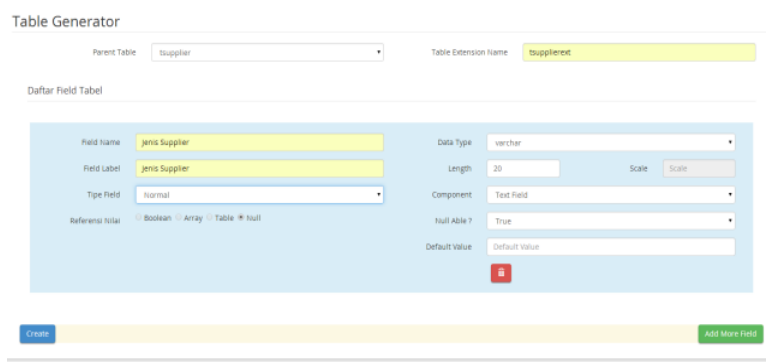

Gambar 9. Form Table Generator

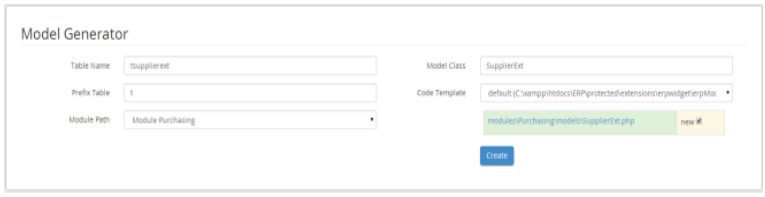

Gambar 10. Tampilan Model Generator

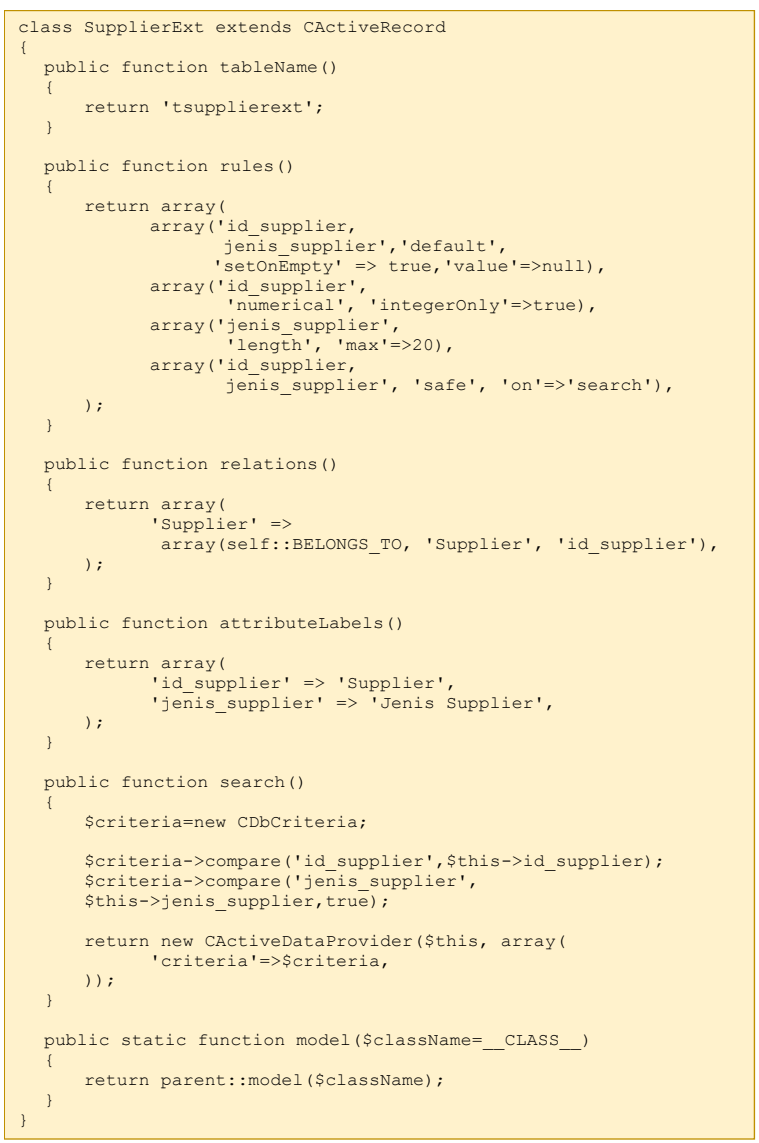

Gambar 12. Hasil Form Generator

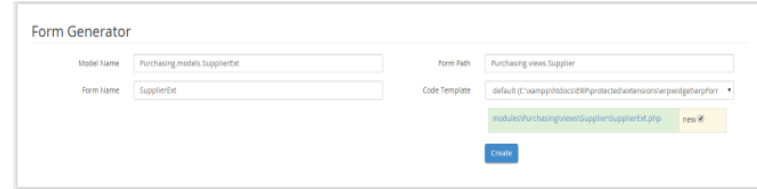

Gambar 13. Tampilan Form Generator

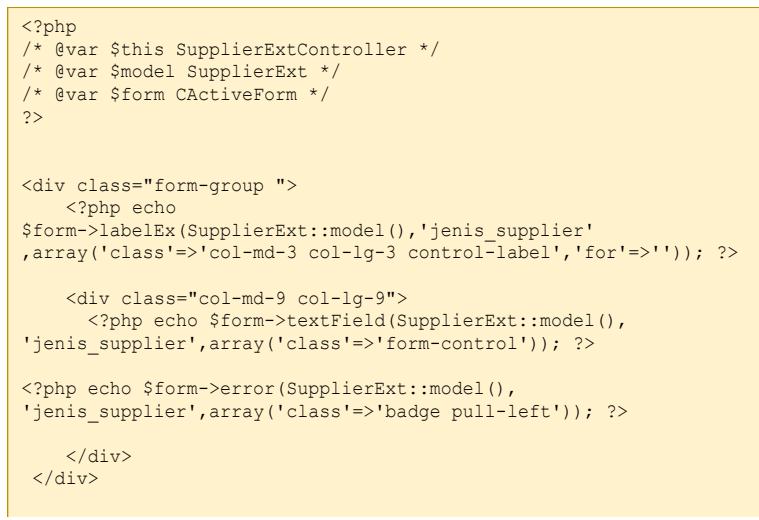

Gambar 14. File Form Hasil Form Generator

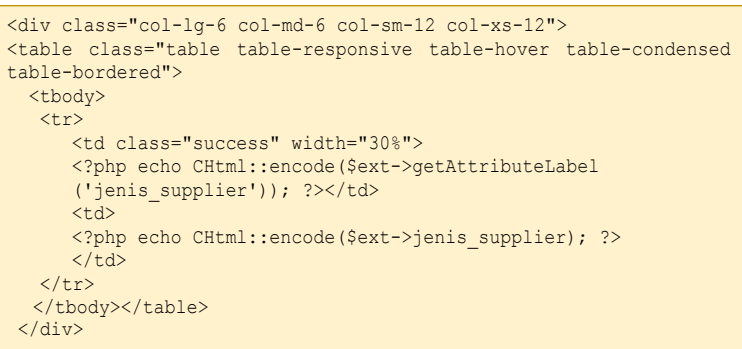

Gambar 15. File Form Hasil Form Generator

File model extension yang dihasilkan model generator digunakan pada form generator sebagai dasar pembuatan file form dan file view. Tampilan form generator dapat dilihat pada dan Gambar 13 dan hasil dari form generator menghasilkan file form dan file view yang isinya dapat dilihat pada Gambar 14 dan Gambar 15.

\section{KESIMPULAN}

Dari hasil perancangan dan pembuatan aplikasi ERP yang diterapkan pada perusahaan UD. Logam utama, dapat diambil kesimpulan antara lain:

- Semua fungsional perusahaan mampu diintegrasian ke dalam satu aplikasi ERP dan satu database terpusat. Hal ini menghasilkan penyebaran informasi yang cepat, efisien dan terkontrol.

- Aplikasi yang dikembangkan ERP menyediakan sejumlah besar fungsi yang mampu menangani proses bisnis yang dimiliki perusahaan. Fungsifungsi yang sediakan mampu menyelesaikan permasalahan dan memenuhi kebutuhan perusahaan di setiap aktivitas bisnis perusahaan. 


\section{DAFTAR PUSTAKA}

[1] Monk, E. B. Concepts in Enterprise Resource Planning 4th Edition. United States of America: Course Technology, Cengage Learning. 2013.

[2] Tenkorang, R. A., Helo. P. Enterprise Resource Planning (ERP): A Review Literature Report. 2011.
[3] Yanis, F. Pentingnya Sistem Enterprise Resource Planning (ERP) Dalam Rangka untuk Membangun Sumber Data pada Suatu Perusahaan. 2013.

[4] Dixit. A. Kr., Prakash, O. A Study of Issues Affecting ERP Implementation in SMEs. 2011.

[5] Magal, S. \& Word, J. Integrated Business Process with ERP Systems. United State: John Wiley \& Sons, Inc. 2012. 